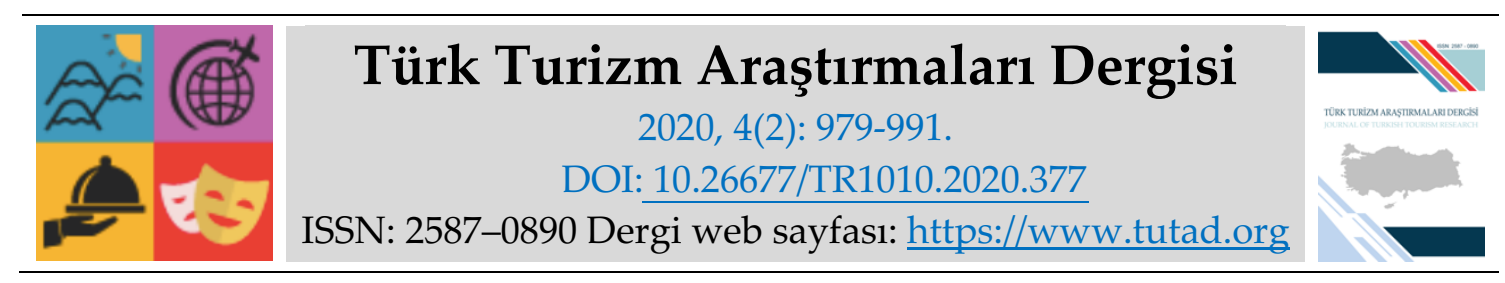

ARASTTIRMA MAKALESI

\title{
Çift-Körleme Hakemlik Sürecinin Etkinliği Konusunda Turizm Akademisyenlerinin Düşünceleri*
}

Dr. Öğr. Üyesi Eray POLAT, Gümüşhane Üniversitesi, Turizm Fakültesi, Gümüşhane, e-posta: eraypolat38@gmail.com

ORCID: https://orcid.org/0000-0003-1470-4298

Öz

Hakemli dergilere gönderilen çalışmalar, çeşitli açılardan kontrol edilmesi amacıyla hakemlik süreci adı verilen denetime tabi tutulmaktadır. Çift-körleme hakemlik süreci (ÇK) de bu süreçlerden biri olarak, turizm disiplininde yer alan bilimsel dergilerce baskın bir şekilde tercih edilmektedir. Ancak son yıllarda ÇK, çeşitli açılardan eleştirilere konu olmaktadır. Bu bağlamda araştırmanın amacı, turizm akademisyenlerinin ÇK hakkındaki düşüncelerini tespit etmektir. Nitel araştırma yöntemlerinin benimsendiği araştırmada, 20. Ulusal Turizm Kongresinin bilim kurulunda yer alan akademisyenler, evreni oluşturmaktadır. Evrenin ulaşılabilir büyüklükte olması nedeniyle örneklem alınmamıştır. Veri toplama amacıyla katılımcılarla elektronik ortamda görüşülerek uygulanan yarı-yapılandırılmış görüşme formu kullanılmıştır. Elde edilen veriler, betimsel analiz yöntemi ile analiz edilmiştir. Sonuçlara göre turizm akademisyenlerinin büyük kısmı (\%69), ÇK'nın, hakem denetimi açısından yeterli olduğunu düşünmektedir. Ayrıca süreç, objektiflik ve kalite güvencesi sağlaması yönünden avantajlara; zaman ve hakemlerin özensiz/dikkatsiz inceleme yapabilmesi yönüyle dezavantajlara sahiptir. Sürecin, editör ve hakemlerin alacağı birtakım önlemlerle daha iyi hale gelebileceği akademisyenlerce öngörülmektedir.

* Bu çalışma, 16-19 Ekim 2019 tarihleri arasında gerçekleştirilen 20. Ulusal Turizm Kongresinde sunulmuş sözel bildirinin genişletilmiş ve güncellenmiş halidir.

Anahtar Kelimeler: Bilimsel Dergi, Akademik Yayın, Hakem, Çift-Körleme Hakemlik Süreci.

Makale Gönderme Tarihi: 25.01.2020

Makale Kabul Tarihi: 11.04 .2020

Önerilen Atıf:

Polat, E. (2020). Çift-Körleme Hakemlik Sürecinin Etkinliği Konusunda Turizm Akademisyenlerinin Düşünceleri, Türk Turizm Araştırmaları Dergisi, 4(2): 979-991.

(C) 2020 Türk Turizm Araştırmaları Dergisi. 


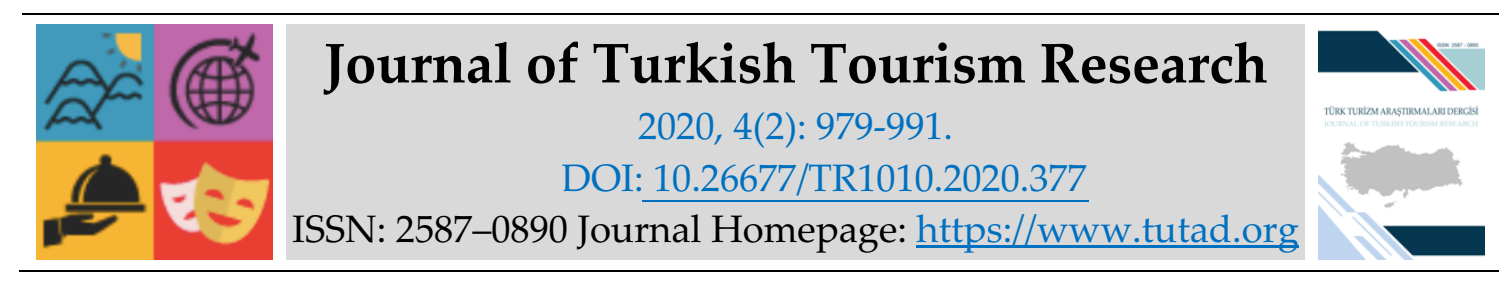

\title{
$\underline{\text { RESEARCH PAPER }}$
}

\section{The Thoughts of the Tourism Academicians on the Effectiveness of the Double- Blind Peer Review Process}

Assistant Prof. Dr. Eray POLAT, Gümüşhane University, Faculty of Tourism, Gümüşhane, email: eraypolat38@gmail.com

ORCID: https://orcid.org/0000-0003-1470-4298

\begin{abstract}
The manuscripts sent to peer-reviewed journals are subjected to an audit called the peer review process in order to control them from various angles. The double-blind peer review process (CK), which is one of these processes, is predominantly preferred by scientific journals in the discipline of tourism and has been carried out for many years. However, in recent years, CK has been subject to criticism in various aspects. In this context, the aim of the study is to determine the thoughts of tourism academicians about the CK. In this research, where qualitative research methods are used, the population consists of the academicians taking part in the scientific committee of the 20th National Tourism Congress. The population is required to be accessible and because of this no need for sampling. The semi-structured interview form, which was interviewed electronically, was used in order to collect data. The obtained data were analyzed by descriptive analysis method. According to the results, tourism academicians (69\%) think that the process increases the quality of the manuscripts. In addition, the process, objectivity and quality assurance in terms of providing advantages; it also has the disadvantages that time and referees can make sloppy review. Finally, it is foreseen by the academicians that the process can be improved by some precautions taken by the editors and referees.
\end{abstract}

Keywords: Scientific Journal, Academic Publication, Referee, Double-Blinded Review Process. Received: 25.01 .2020

Accepted: 11.04 .2020

\section{Suggested Citation:}

Polat, E. (2020). The Thoughts of the Tourism Academicians on the Effectiveness of the DoubleBlind Peer Review Process, Journal of Turkish Tourism Research, 4(2): 979-991.

(C) 2020 Türk Turizm Araştırmaları Dergisi. 


\section{GİRIŞ}

Bilginin yayılması sürecinde kitaplar ile hakemli dergiler, birbirinden farklı fonksiyonlar yüklenmişlerdir. Kitaplar, genelde ele alınan kavram ya da problem hakkında bilgi verme mahiyetinde bir işleve sahipken; hakemli dergiler daha çok son gelişmelerin neler olduğu veya güncel araştırma bulguları hakkında bilgi vermektedir (Dilek-Kayaoğlu ve Gülle, 2015: 392). Bilimsel dergiler bunu yaparken, yayınlanmaya aday çalışmaları kalite denetiminden geçirmektedir. Özellikle II. Dünya Savaşı sonrasında örgütlü bir şekilde gerçekleştirilen ve hakem denetimi olarak bilinen bu süreçte, konu hakkında bilgisi/deneyimi olan hakemlerin incelemesi ile bilimsel çalışmaların kalitesi, doğruluğu veya faydalı sonuçlar içerdiği gibi ölçütleri yerine getirdiği varsayılmaktadır.

Son yıllarda yazında, hakemlik sisteminin fayda sağlamaktan uzak ve çeşitli maliyetleri olan bir uygulama olduğu yönünde eleştiriler de bulunmaktadır. Bununla birlikte bilimsel etik ilkelerinin ihlal edildiği ve bu konuda yazar, editör ve hakemlerin üstlerine düşen sorumlulukları niteliğine uygun bir şekilde yerine getiremedikleri ifade edilmektedir (Seaton, 1996; Yuksel, 2003; Şahin, 2006; Glonti ve Hren, 2018; Sanchez vd., 2019). Bu noktada, yüz yıllardır uygulanan hakemlik sisteminin artık günümüz beklentilerini tam olarak karşılayamadığı ve bilimsel yayınlardaki kalite artışını sağlama işlevini yerine getiremediği gibi sorunlar akla gelmektedir.

İşte bu araştırma temel olarak, turizm akademisyenlerinin hakemlik süreçlerinden biri olan ÇK'ya bakış açısının ne olduğunu tespit etmeyi amaçlamaktadır. Yazında çeşitli bilim dallarından akademisyenlerin, ÇK hakkındaki düşüncelerini tespite yönelen çalışmaların olduğu görülmektedir. Ancak konu hakkında turizm akademisyenlerinin düşüncelerini tespit etmeye çalışan araştırma sayısının sınırlılığı göze çarpmaktadır. Araştırmacının tespitlerine göre özellikle yerli yazında herhangi bir çalışmaya rastlanılmaması, bu çalışmanın çıkış noktasını oluşturmaktadır. Hâlbuki ülkemizde artan turizm programları sayesinde turizm araştırmalarının sayısı günden güne artmaktadır. Bu araştırmaların usulüne uygun bir şekilde yapılması, hatalardan arınmış bir şekilde raporlaştırılması ve böylelikle alandaki mevcut bilgi birikiminin daha da geliştirilmesi adına hakemlik sisteminin etkin bir biçimde işletilmesi gerekmektedir. Bu da ancak mevcut uygulamaya karşı duyulan rahatsızlıkların varsa tespit edilmesi ve düzeltilmeye çalışılması ile mümkün olabilecektir. Bu kapsamda, çalışmada şu sorulara cevap aranacaktır:

- Turizm akademisyenleri, ÇK'nın uygulamalı makalelerdeki kalitenin artmasına hizmet ettiğini düşünmekte midir?

- Turizm akademisyenleri, ÇK'nın avantaj ve dezavantajları hakkında neler düşünmektedir?

- Turizm akademisyenleri, ÇK'nın iyileştirilmesi adına ne tür önerilere sahiptir?

\section{KAVRAMSAL ÇERÇEVE VE İLGİİ ALANYAZIN}

Dünyada, bilimsel dergi niteliği taşıyan ilk örnekler, Fransa'da Journal des Sçavans, İngiltere'de Philosophical Transactions isimleri ile 1665 yılında ortaya çıkmıştır (Dilek-Kayaoğlu ve Gülle, 2015: 393). Bu dergiler yayınlanmaya başladıkları ilk yıllarda, gelen çalışmalar için herhangi bir hakem denetimi öngörmemiştir (Baldwin, 2018: 539). Bu nedenle birçok kişi, ilk hakem denetimli dergi olarak 1731'de Edinburgh Kraliyet Akademisince yayınlanan Medical Essays and Observations isimli dergiyi işaret etmiştir (Tan, 2018: 55). Ayrıca hakemlik sürecinin temellerinin atılmasında Londra Kraliyet Akademisi tarafından yayınlanan Philosophical Transactions dergisinin ilk editörü Henry Oldenburg'un katkıları da önemlidir. Çünkü dergiye gelen çalışmaların bir süzgeçten geçirilmesi gerektiğini düşünerek, ileriki yıllarda bunu sağlayacak komitenin kurulmasına 
öncülük etmiştir (Kronick, 1990: 1321). Böylelikle 1752 yılında Philosophical Transactions, hakem denetimini uygulamaya koyan ikinci dergi olmuştur. 1893 yılında ise British Medical Journal ve editörü Ernest Hart, günümüzdeki şekliyle hakemlik sürecini başlatan ilk örnekler olarak ifade edilmektedir (Winck vd., 2011: 96). II. Dünya Savaşı sonrasındaki dönemde ise hakemlik sürecinin daha da kurumsallaştığı ve üzerine çok ciddi emek ve zaman harcanan bir dönem olduğu söylenebilir (Baldwin, 2018: 540). Zira John Wiley'in 2015'te yaptığ bir anketin sonuçlarına göre 2013'te önde gelen 12 yayıncıya sunulan çalışmaları incelemek için hakemler, 22 milyon saatten fazla zaman harcamıştır (Correia ve Kozak, 2017: 2).

Günümüzde bu denli önem kazanan ve kurumsallaşan hakemlik sürecinin bugüne kadar hala üzerinde mutabık kalınan evrensel bir tanımının yapılmadığ 1 ifade edilmektedir (Glonti ve Hren, 2018: 1). Ancak bazı kurum/kuruluşlar kendi takipçilerinin itibar ettiği tanımlar da yapmıştır. Örneğin, Tıp Dergileri Editörleri Uluslararası Komitesince hakemlik süreci, bir dergiye sunulan çalışmaların, derginin editör kadrosunda yer almayan uzmanlarca, kalite, uygunluk ve doğruluk gibi çeşitli kıstaslar açısından değerlendirilmesi şeklinde tanımlamaktadır (Hames, 2007: 1). Yazında konu hakkında yapılan farklı tanımlar da dikkat çekmektedir. Örneğin bu süreci, Hill (2016: 109) "sapla samanı birbirinden ayırmak" şeklinde, Bornmann ve Daniel (2010: 5) ise akademik yayıncılıktaki kalitenin artması adına "sosyal bir mekanizma" olarak nitelemektedir.

Hakemlik süreci, bilimsel kalitenin artması açısından bazı avantajlar sağlamaktadır. Öncelikle bu süreç, yayınlanmaya aday çalışmaların kalitesinin artmasına iki yolla hizmet etmektedir. Birincisi, yazarları, daha yazım aşamasında iken kaliteyi artırma yönünde motive etmektedir. İkincisi, çalışmalarda hakem ve/veya editörlerin geri dönüşlerine göre revizyonlar yapılması da kaliteyi artırmaktadır (Ware, 2013: 5).

Bir filtreleme süreci olan hakemlik süreci, okuyuculara da faydalar sağlamaktadır. Özellikle belirli bir konu üzerinde çalışan okuyucular, hakem sürecindeki filtreleme ile iyi çalışmaların, iyi ve konuya uygun dergilerde yer alacağını (Ware ve Mabe, 2015: 47) ve hakem denetiminden geçerek yayımlanan bir çalışmanın akademik yazım standartlarına uygun olacağını tahmin edebilmektedirler (Yüksel, 2002: 140). Aynı zamanda süreç, hatalı araştırma ve çıktılarına da bariyer olarak okuyucuların doğru bilgiye erişimini sağlamaktadır (Ware, 2013: 5). Diğer taraftan bu fayda, toplumun ve proje desteklemeye gönüllü kurum/kuruluşların bilimsel yayınlara olan güvenini de artırmaktadır.

Birçok araştırmada, araştırmacıların hakemlik sürecini etkin bir mekanizma olarak gördükleri ve destekledikleri tespit edilmiştir (Ware, 2008: 12). Ancak hakemlik sürecine bazı eleştiriler de yöneltilmektedir. Bunlardan biri, zaten doğasında sübjektif olan sürecin, bir de hakemlerin çalışmaları incelemek için herhangi bir eğitim almaması* (Glonti ve Hren, 2018: 1) ile birleşmesi sonucunda, tamamen farklı değerlendirmelerin ve önerilerin ortaya çıabilmesidir. Bu durum, sürecin güvenilmez ve önyargılar içeren bir süreç olarak görülmesine yol açmaktadır (Ware ve Mabe, 2015: 47). Tan (2018: 64)'ın değindiği konu, buna örnek olarak verilebilir. Yazar, ABD'de yayınlanan tıp alanındaki bazı dergilerden "ret" cevabı alan çalışmaların, \%41-\%64 arasındaki oranlarda ve 15-28 hafta sonrasında başka dergilerde yayınlandığını tespit etmiştir. Sürecin güvenilmezliğine yol açabilecek bir diğer neden, hakemlerin, çalışmaların yayınlanabilir ya da yayınlanamaz olduğuna ilişkin gerekçelerini bazen hiç sunmaması bazen de sadece birkaç cümle ile ifade etmesinden de ileri gelmektedir. Oysaki etkili bir değerlendirme yapan hakem, kararının gerekçelerini sağlam bir zemine oturtabilmeli ve bunu karşı tarafa anlaşılır bir şekilde sunabilmelidir (Şahin, 2006: 65).

\footnotetext{
" Bir araştırma sonuçlarına göre tıp alanında hakemlik yapanların sadece \%14'ü bu konuda eğitim almıştır
} (Snell ve Spencer, 2005). 
Hakemlerin raporlarını sunarken kullandıkları dil de sürece gölge düşürebilmekte ve eleştirilmesine zemin hazırlamaktadır. Şahin (2006: 66), bir dergiye sunulan çalışmaların hakem raporlarını incelediği çalışmasında, hakemlerin, "işe yaramaz bir çalışma", "kendini otorite mi sandın", "ancak bu kadar kötü ifade edilebilirdi" gibi rahatsızlık verici ifadeler kullandığını tespit etmiştir. Ayrıca bunun, hakemlerin çalışmayla ilgili geçerli değerlendirmelerini gölgelediği de belirtilmektedir.

Hakemlik sürecine yöneltilen eleştiriler arasında, dergi editörlerinin kimi zaman taraflı davranarak hakemleri, istediği sonuca göre ataması da bulunmaktadır (Yuksel, 2003: 438). Böylelikle editörler, istediği çalışmaların yayınlanma olasılığını artırırken, istemediği çalışmaların yayınlanma olasılığını azaltarak sürece, bilimsel etik ilkelerine aykırı düşer şekilde müdahalede bulunabilmektedir. Bu noktada Seaton (1996: 398), turizm yazını açısından "eski tutuculukları"na devam eden bir "akademik mafya"nın varlığına ve bu oluşumun, çalışmaların yayınlanıp yayınlanmama kararında ciddi bir rolünün olduğuna değinmektedir. Benzer olarak, hakemlerin yeni fikir ve uygulamaları kabullenmede, mevcut ideolojilere daha uyumlu olanlara kıyasen daha isteksiz davranabildiği de dile getirilmektedir (Sanchez vd., 2019: 3). Bu durum, alandaki mevcut teori veya uygulamalara yeni bakış açıları getiren çalışmaların elenmesine ve gün yüzüne çıkamamasına yol açabilmektedir.

Hakemlik sürecindeki sorunlar, hakemlerin inceledikleri çalışmanın konusu veya metodolojisi hakkında yeterli bilgiye sahip olmamasından da kaynaklanabilmektedir (Erdoğan 2001). Buna, editörlerin bilgi yetersizliği nedeniyle yanlış hakem ataması da dahil edilebilir (Correia ve Kozak, 2017: 3). Bu durum, çalışmaların ciddi eksiklik, hata ya da etik ihlallerle birlikte yayınlanmasına yol açabilmektedir. Bu eleştirileri kimi zaman "haklı gösterebilecek" kayda değer bir örnek, 1985 yılında Slutsky olayı adıyla Kaliforniya Üniversitesi'nde yaşanmıştır. Doçentlik başvurusu ile yayınları incelemeye alınan Robert Slutsky'nin iki araştırmasında sonuçların birebir aynı olduğu görülmüş ve bu nedenle tüm yayınları incelenmeye başlanmıştır. İnceleme sonucunda yazarın yaptığ1 137 yayının büyük bir kısmında birçok sorun olduğu (hak edilmemiş yazarlık, fabrikasyon, istatistiki hatalar vb.) tespit edilmiştir. Bu sorunların nasıl gözden kaçırıldığı sorgulandığında ise yazarın, yayınlarında "ünlü" akademisyenlerle ortak yazarlık yaptığı ve böylelikle makalelerinin ciddi bir hakemlik süreci ile karşılaşmadığı anlaşılmıştır (Aydın ve Yüksel, 2013: 4). Buna ek olarak yanlış hakem ataması, nitelikli çalışmaların elenmesine de yol açabilmektedir. Buna çarpıcı bir örnek, George Akerlof'un 1967'de hazırladığı, “The Market for Lemons: Quality Uncertainty and the Market Mechanism" ismindeki makalesidir. Bu makale, o dönemde gönderildiği üç dergiden ret cevabı almış ancak yazara, 2001 Nobel Ödülünü getirmiştir (Aydın ve Yüksel, 2013: 4).

Esasında editörlerin, hakem atamalarını uzmanlık alanlarına göre yapması ve böylelikle hataların önüne geçmesi beklenir. Ancak son dönemlerde artan araştırma sayısına bağlı olarak bunun, bazen göz ardı edilebildiği akla gelmektedir. Hakemlik sürecinin özünde bulunan "gönüllülük" esası da buna yol açabilmektedir (Shani, 2018: 75). Zira konu hakkında uzmanlığ1 bulunan ancak çalışmayı değerlendirmek istemeyen hakemler nedeniyle çalışmalar, normal koşullarda gitmeyeceği hakemlere gidebilmektedir. Dahası, gönüllülük esası, çalışmaların değerlendirme sürecinin yavaşlamasına ve uzamasına yol açabilmektedir (Shani, 2018: 75). Bu nedenle özellikle genç yazarlar süreç boyunca yıpranabilmekte ve kurumlar/toplum araştırma sonuçlarından daha geç haberdar olmaktadır.

Günümüzde hakemlik süreci, dört farklı şekilde uygulanmaktadır. İlki, yalnızca hakemin, yazarın kimliğini bildiği (Ware, 2008: 6) tek-körleme (single-blind) hakemlik sürecidir. Bunda, hakemin, kimliğinin gizliliği ile eleştirilerini yaparken, rahat ve dürüst davranabileceği varsayılmaktadır. Ancak yazarın, hakemin kariyerine etki etme potansiyeli varsa, bu, hakemi olumlu/olumsuz manada etkileyebilir (Ware, 2013: 12). İkinci hakemlik türü, hakem ve yazar 
olarak iki tarafın da kimliğinin birbirlerinden gizlendiği çift-körleme (double-blind) hakemlik sürecidir. Bu gizliliğin, incelemeyi çalışma üzerinde yoğunlaştıracağı ve adaleti sağlayabileceği düşünülmektedir. Ancak bu durumda hakemin eleştirilerinde ölçüsüz davranabildiği ve ideolojisini beğenmediği çalışmaları kolayca reddebildiği de vakidir (Önder, 2006: 50).

Son yıllarda uygulamaya geçen hakemlik süreci ise açık (open) hakemlik sürecidir. Bu modelde, hakem ve yazarların kimlikleri taraflarca bilinmektedir. Süreç sonunda isteğe bağlı olarak hakemlerin isimleri ve raporları çalışma ile birlikte yayınlanmaktadır. Bu sürecin açıklık, adalet ve hesap verilebilirlik şartlarını sağlamada diğerlerine nazaran daha başarılı olduğu addedilmektedir. Buna karşın hakemlerin, tek-körleme sürecinde olduğu gibi yazarların kimliğinden etkilenebilmesi de söz konusudur (Ware, 2011: 37-38).

Dördüncü hakemlik süreci ise yayım sonrası (post-publication) hakemlik sürecidir. Bu uygulamanın özünde sadece hakemlerin değil, erişebilen herkesin çalışmayı inceleyebilmesi, yorum yapabilmesi ve puan verebilmesi söz konusudur. Buna örnek bir uygulama Atmospheric Chemistry $\mathcal{E}$ Physics dergisi tarafından yürütülmektedir (Ware, 2011: 73). İki aşamalı süreçte, gelen çalışmalar öncelikle, ön-incelemeye tabi tutulmakta ve derginin web sayfasında "tartı̧ma çalışmaları" olarak yayınlanmaktadır. Sekiz hafta süresince, çalışma hakkında atanan hakemlerle birlikte isteyen kimseler de eleştiri yapabilmekte ve yazarlar buna cevap verebilmektedir. Tüm bunlar kamuya açık bir şekilde yapılmaktadır. İkinci aşamada, çalışma ile ilgili hakem incelemesi ve revizyonlar, diğer kesimlere kapalı şekilde, geleneksel hakem süreçlerine göre yapılmakta ve çalışma kabul edilirse son hali dergide yayınlanmaktadır (Koop ve Pöschl, 2006).

Yazında, hakemlik sürecinin geliştirilmesi ve iyileştirilmesi, aksi halde dergilerin prestij ve okuyucu kaybedebileceği belirtilmektedir (Leung vd., 2014: 47). Açık ve yayım sonrası hakemlik süreçleri, yeni ve iyileştirilmiş süreçler olarak düşünülebilir zira bunlar denenmeye yeni başlanmış uygulamalardır. Ware (2008: 7)'in araştırması bunu teyit etmektedir. Araştırmanın sonuçlarına göre, yazarların \%85'i tek-körleme, \%45'i çift-körleme, \%23'ü açık ve \%8'i yayım sonrası hakemlik sürecini deneyimlemiştir. Ancak bu yeni süreçlere, hakemlerin ve araştırmacıların çok sıcak bakmadıkları görülmektedir. Zira Greaves vd., (2006) Nature dergisi yazarlarının, derginin 2006 yılında denediği açık hakemlik sürecine olumlu bakmadıklarını tespit etmiştir. Bravo vd. (2019)'nin çalışmasında ise açık hakemlik süreçlerinin gerek şartlarından biri olan hakem kimliğinin açık edilmesi hususuna, hakemlerin yalnızca \%8,1'inin destek vereceği belirtilmektedir.

Çeşitli kesimlerin hakemlik süreçlerinin işleyişine bakış açıları incelendiğinde, genel olarak memnun bir kitle görülmektedir. Yazında, bir taraftan mevcut uygulamalarda iyileştirmeler yapılması gerektiğinden dem vurulmakta, diğer taraftan bunlara alternatif olabilecek yeni uygulamalara destek noktasında gönülsüz davranılmaktadır. Örneğin, Baggs vd., (2008) hemşirelik alanında görev alan hakem ve editörlerin, ÇK'yı büyük oranda $(\% 93,6)$ desteklediklerini ifade etmektedir. Pazarlama akademisyenleri, mevut hakemlik sürecinin kalitesine, 100 üzerinden ortalama olarak 72 puan vermektedir (Bailey vd., 2012). Yerli yazındaki tek çalışmada ise Dilek-Kayaoğlu ve Gülle (2015), yazarların \%87'sinin mevcut hakemlik sürecinden memnun olduklarını tespit etmiştir.

Konu hakkında turizm disiplini özelinde Leung vd. (2014)'nin çalışması göze çarpmaktadır. Bu araştırmada, turizm alanında yapılmış çalışmaları incelemiş hakemlerin görüşleri tespit edilmiştir. Elde edilen sonuçlara göre, hakemlerin büyük bir oranda (\%88) ÇK'yı yeterli gördüğü ve çalışmaların kalitesini artıran bir süreç olduğu dile getirilmiştir. 


\section{YÖNTEM}

Çeşitli eleştirilere konu olan ve revize edilerek iyileştirilmesi gerektiğinden dem vurulan hakemlik süreçlerinin (özellikle de tek/çift-körleme hakemlik süreçleri) mevcut durumu konusunda turizm akademisyenlerinin ne düşündügü yazında çok net belirlenmemiştir. Ancak tüm dünya çapında turizm disiplininde yayınlanan (uluslararası) dergilerin sayısı 300'ü aşmış, 2016 yılı itibariyle turizm konusunda yayınlanan makalelerin sayısı yaklaşık 55.000'e ulaşmış durumdadır (Correia ve Kozak, 2017: 2). Bu rakamlar ile hakemlerin ve hakemlik sistemlerinin üzerinde büyük bir yük bulunduğu söylenebilmektedir. Ancak mevcut sisteme dair görüşlerin ne olduğu, iyileştirilmesi gereken yönlerinin bulunup bulunmadığı gibi hususlar açısından yeterli araştırmanın yapılmadığı görülmektedir. İşte bu araştırma ile hakemlik süreçlerinden biri olan ve turizm disiplininde ağırlıklı olarak kullanılan ÇK'nın turizm akademisyenlerince nasıl değerlendirildiğinin tespit edilmesi ve böylelikle alan yazındaki boşluğa katkı sağlamak amaçlanmaktadır. Bu nedenlerle araştırmanın önem taşıdığı düşünülmektedir.

$\mathrm{Bu}$ araştırma, mevcut durumu var olan şekli ile ortaya koymaya çalıştığından betimsel bir araştırmadır. Araştırma evrenini, 20. Ulusal Turizm Kongresinin bilim kurulunda yer alan öğretim üyeleri oluşturmaktadır. Evrenin bu şekilde belirlenmesinin nedeni, kurulda sadece "profesör doktor" unvanı taşıyan kişilerin bulunması ve bu kişilerin mevcut hakemlik süreçleri kapsamında Türkiye'de turizm disiplinindeki "en deneyimli" kişiler olduğu düşüncesidir. Evren, 1 Nisan 2019 tarihi itibariyle toplam 96 kişiden oluşmaktadır. Evrenin ulaşılabilir büyüklükte olması nedeniyle örneklem alınmamış, tam sayım yöntemi kullanılmıştır.

Araştırmanın amacı doğrultusunda hazırlanan görüşme formu katılımcıların e-posta adreslerine tek tek gönderilmiştir. Form, e-posta adreslerine ulaşılamayan kişiler haricindeki 91 kişiye 3 Nisan'da gönderilmiştir. 25 Nisan'a kadar 10 kişiden cevap alındıktan sonra katılım göstermeyen 81 kişiye ikinci defa e-posta gönderilmiştir. 15 Mayıs tarihine kadar, altı kişinin daha katılım göstermesi üzerine veri toplama işlemi sonlandırılmıştır. Veri toplama işleminin bu aşamada sonlandırılmasının nedeni, alınan yanıtların kendini tekrar etmeye başladığının görülmesi ve bu nedenle doygunluğa ulaşttğının düşünülmesidir. Bu bağlamda, toplam 16 kişiden yanıt alınmıştır (\%17). Katılımcılar veri analizi aşamasında k1, k2 şeklinde kodlanmıştır.

Veri toplama aracı olarak yarı-yapılandırılmış görüşme formu kullanılmıştır. Katılımcıların görüşleri ile demografik özellikleri arasındaki olası ilişkinin tespiti, araştırmanın ana hedefi olmadığından formda bu sorulara yer verilmemiş, bunun yerine araştırma sorularını yanitlayacağı düşünülen üç adet açık uçlu soru sorulmuştur. Açı uçlu sorulardan oluşan kısa bir anketin tercih edilme sebebi, bunun yanıt oranını artıracak olması, ekonomik olması ve katılımcıların düşüncelerini araştırmacı tarafından belirlenen şablon ile sınırlamadan, kendi düşüncelerini özgürce ifade etmelerine olanak tanımasıdır (Yüksel, 2002: 141). Sorulardan ilki, ÇK'ya yönelik olumlu ve olumsuz düşünceleri tespit etmeye çalışmaktadır (S1: Çift-körleme hakemlik sürecinin uygulamalı makalelerdeki kalitenin artmasına hizmet ettiğini düşünüyor musunuz?). İkinci soru katılımcıların ÇK'nın sahip olduğu avantaj ve dezavantajlar hakkındaki düşüncelerini almak amacındadır (S2: Çift-körleme hakemlik sürecinin avantaj ve dezavantajları hakkında neler düşünüyorsunuz?). Son olarak üçüncü soru, sürecin iyileştirilmesi adına katılımcıların mevcut olabilecek önerilerini belirlemeye odaklanmıştır (S3: Çift-körleme hakemlik sürecinin daha da iyileştirilmesi adına ek görüş ve öneriniz var mı?). Formdaki sorular, Leung vd. (2014)'nin çalışmasından uyarlanmıştır. Yazarların, formun içerik geçerliğini sağlayabilmek için uzman görüşü almış olması nedeniyle içerik geçerliliğinin sağlandığı kabul edilmiştir.

Verilerin analizinde betimsel analiz kullanılmıştır. Betimsel analiz, elde edilen verilerin daha önceden belirlenen başlıklar (temalar) altında özetlenmesi ve yorumlanmasıdır. Bu analizde elde edilen verilerin sınıflandırılması araştırma sorularına göre yapılabileceğinden (Altunışık vd., 
2010: 322), toplanan veriler ilgili soru altında sınıflandırılmış ve analiz edilmiştir. Veri analizinin geçerlik ve objektifliğinin sağlanabilmesi amacıyla Göktaş vd. (2012: 181)'nin izlediği yol takip edilmiştir. İlk aşamada verilerin tamamı araştırmacı tarafından incelenmiş ve araştırma sorularının altında belirlenen temalara yerleştirilmiştir. Hall ve Valentin (2005: 196) bu aşamada aksaklıkların giderilmesi, görüş ayrılıklarının üzerinde tartışılması ve gözden kaçan verinin olmaması için incelemeyi en az iki araştırmacının yapmasının daha uygun olacağını belirtmektedir. Bu nedenle, nitel veri analizi konusunda deneyimi bulunan bir araştırmacıdan daha destek alınmıştır. İncelemenin ikinci evresinde, araştırmacıların ayrı ayrı yaptığı temametin uyumu karşılaştırılarak, farklılıklar üzerinde tartışılmış ve giderilmeye çalışılmıştır. Son aşamada ise veri analizi ile ortaya çıan bulgular yeniden gözden geçirilmiş ve son hali verilmiştir. Bu sayede çalışmanın geçerlik ve objektiflik kriterlerini sağladığı varsayılmıştır.

\section{BULGULAR VE TARTIŞMA}

\section{Çift-Körleme Hakemlik Sürecinin Kaliteyi Artırma Potansiyeli}

İlk soru, ÇK'nın uygulamalı makalelerdeki kalitenin artmasında fayda sağlayıp sağlamadığı konusunda katılımcıların düşüncelerini tespit etmek amacındadır. Katılımcıların 11'i (\%69) ÇK'nın, çalışmaların kalitesini artırdığını düşünmektedir. Bu konuda bir katılımcı "kesinlikle hayır" yanıtını verirken; dört katılımcı "kısmen" yanıtını vermiştir. Kısmen yanıtını veren katılımcılardan biri (k15) çalışmaların kalitesinin artması konusundaki esas belirleyici unsurun, "hakemin yeni yaklaşımları kabul edebilme derecesi ve çalışmaya yeni öneriler getirebilme becerisine" bağlı olduğunu ifade etmiştir. Başka bir katılımcı (k6) kalite artışının, "hakemlerin yeterli özeni göstermesi ve dergi politikalarına" bağlı olduğunu ifade etmiştir.

ÇK'nın, çalışmaların kalitesini artırdığını düşünen akademisyenler, sürecin "objektif değerlendirmelere imkan verdiğini (k9)" ifade etmektedir. Aksi halde "sübjektif değerlendirmelerin sayısının artacağı (k2)" dile getirilmektedir. Buna ek olarak, yayınlanma sürecine hakemin de dahil olmasıyla çalışmalar farklı bakış açıları kazanabilmekte ve "yazarların göremediği eksiklikler giderilebilmektedir (k5)". ÇK'nın "kesinlikle" kaliteyi artırmadığını ifade eden bir akademisyen ise görüşünü "editörlerin, hakemleri duruma göre seçtikleri $(k 1)$ " argümanıyla desteklemektedir. Bu ifade Seaton (1996)'ın turizm yazınındaki varlığına değindiği ve hangi çalışmanın yayınlanıp hangisinin yayınlanmayacağı konusunda ciddi rolünün olduğunu iddia ettiği “akademik mafya"nın, günümüzde de varlığını devam ettirdiğini akla getirmektedir.

Sonuçlar, daha önce konu hakkında yapılmış çalışmalarla (Bailey vd. 2008a, 2008b, 2012; Leung vd. 2014) örtüşmektedir ve bu sonuçlarla turizm akademisyenlerinin ÇK'ya karşı olumlu bir tutum taşıdıkları söylenebilmektedir. Bu kısımda dikkati çeken bir görüş ise çalışmaların kalitesini artıran esas unsurun, hakemin yeniliklere ne derece açık olduğuna ve çalışmadaki muhtemel eksikliklere karşı yeni öneriler sunma/sunabilme isteğine/becerisine bağlı olduğu şeklindedir.

\section{Çift-Körleme Hakemlik Sürecinin Avantajlar ve Dezavantajları}

Katılımcların görüşleri ile ÇK'nın avantajları, (1) objektiflik ve (2) kalite güvencesi sağlaması olarak boyutlandırılabilir. Bu boyutlar, Leung vd., (2014)'nin araştırmasında ortaya çıkan boyutlar ile benzeşmektedir. 
ÇK'nın objektifliği sağlaması en önemli avantajı olarak görülmektedir. Çünkü hemen hemen tüm katılımcılar buna değinmiştir. Sürecin yapısı gereği, tarafların kimliklerinin gizliliğ̈i, "hakemin sadece konuya odaklanmasına firsat vermekte (k7)", "nesnel (k8)" ve "tarafsız bir değerlendirmeye (k2)" imkan tanımaktadır. Ayrıca bir katılımcı, bu gizliliğin "hakemlerin de birbirini yönlendirme olasılığını ortadan kaldırdığını (k10)" belirterek, hakemler arasında iletişim olmamasının da objektifliği artırdığına değinmektedir.

ÇK'nın, ikincil olarak önemli görülen avantajı, kalite güvencesi sağlaması şeklindedir. Katılımcılar, yazarların kontrolüne rağmen çalışmaların, ÇK ile "ikincil bir kontrolden geçmesi (k10)" ve böylelikle "eksiklik/hataların daha kolay giderilerek (k5)", kalitenin artabileceğine değinmektedir. Başka bir katılımcı (k15), "alanda uzman ve birden fazla kişinin" incelemesi ile çalışmaya yeni bakış açıları katılacağını ve kalitenin artacağını belirtmektedir. Ayrıca kimi zaman hakemlerin "farklı disiplinlerden olması ile bu bakış açısının daha genişleyeceği ve çeşitleneceği (k8)" vurgulanmaktadır.

ÇK'nın dezavantajları incelendiğinde ise bir katılımcı (k9), ÇK'nın herhangi bir dezavantajı olmadığını ifade etmiş, diğer katılımcılar ise çeşitli dezavantajlara değinmişlerdir. Bu dezavantajlar, (1) zaman ve (2) hakemlerin özensiz bir şekilde inceleme yapması olarak boyutlandırılabilir. Leung vd., (2014) de zaman boyutunu ÇK'nın dezavantajlarından biri olarak tespit etmiştir.

Hakemlik süreci, çalışmanın dergiye önerilmesi ile başlamakta, olumlu hakem raporları ve editör görüşünün alınması ile son bulmaktadır. Bu sürecin kimi zaman uzayabilmesi, ÇK'nın en önemli dezavantajı olarak görülmektedir. Bailey vd., (2008a, 2008b) de bu hususun, ÇK'nın en çok şikâyet edilen konusu olduğuna değinmektedir. Katılımcılar, "günümüzde araştırma sayısının yanı sıra akademisyenlerin idari görevlerinin de arttığına (k6)" değinerek, "iş yükü fazla olan akademisyenlerin (k8)", çalışmaları değerlendirmek için "yeterli zamanı ayıramadığını ve bu nedenle sürecin tamamlanmasının uzun sürdügünü $(\mathrm{k} 4)^{\prime \prime}$ belirtmektedir. Ayrıca bir başka katılımcı (k14), yayınlanma süresinin uzamasını "yazar ile hakem arasında doğrudan iletişim kurulamamasına" bağlamaktadır. Bunu, yazar ile hakem arasında editörlüğün konumlanmış olmasının, iletişim süresini uzattığı şeklinde anlamak da mümkündür.

Hakemlerin özensiz bir şekilde inceleme yapması, ikinci sırada gelen dezavantaj olarak belirlenmiştir. Katılımcılar, bu özensizliği, çalışma için "yeterince zaman harcanmaması (k5)", "hakemlerin yoğunluğu (k11), (k8)" gibi sebeplere bağlamaktadır. "Hakem raporlarında, yazardan istenilen değişikliklerin açık ve net dile getirilmemesi (k14)" ve "hakemin çalışmada zaten mevcut olan düzeltmeleri istemesi (k3)" hususlarını da bu kapsamda ele almak mümkündür. Correia ve Kozak (2017: 9), hakemlerin özensiz ve yetersiz inceleme yapmasında, editörler tarafından yapılan zaman baskısının da rolü olabileceğine değinmektedir. Bu konuda bahsedilen diğer bir husus, "hakemlerin yazındaki yenilikleri yeterince takip etmemesi ve bilgi/becerilerini güncellememesi nedeniyle yazında artık kabul görmeyen uygulamaları istemeleri (k16)" şeklindedir. Bu, Seaton (1996: 398)'ın değindiği ve yukarıda bahsedilen, eski tutuculuklarına hala devam eden ve kendilerini yenilemeyen bir kitlenin varlığının, günümüzde devam ettiğine dair ikinci bir kanıt olarak sunulabilir.

ÇK'nın dezavantajları kapsamında bahsedilen iki boyut haricinde şunlara da değinilmiştir. Bir katılımcının (k8), hakemlerin bazen farklı disiplinlerden olması ile çalışmadaki bakış açısının genişleyeceğine, ÇK'nın bir avantajı olarak değindiği belirtilmişti. Ancak farklı bir katılımcı (k10) bunu bir dezavantaj olarak nitelemekte ve farklı disiplinlerden hakemlerin, "çalışmayı istenmeyen bir noktaya taşıyabileceğini" ifade etmektedir. Ek olarak başka bir katılımcı (k14), "inceleme esnasında hakemin veya yazarın kimliğinin açığa çıkabilme ihtimalini", sürecin bir dezavantajı olarak değerlendirmektedir. 


\section{Çift-Körleme Hakemlik Sürecinin İyileştirilebilmesi Adına Öneriler}

Son soruda, ÇK'nın daha iyi bir süreç olabilmesi için (varsa) katılımcıların önerilerini almak hedeflenmiştir. Yapılan öneriler, hakemler ve editörler ile ilgili olarak iki başlık altında toplanabilir. Bu konuda Baliey vd., (2008a, 2008b)'nin çalışmalarında, en çok hakemler hakkında öneriler olduğu görülmektedir. Hakemler ile ilgili öneriler, "hakemlere incelemeleri karşıllğında ücret ödenmesi (k5-k12)" veya bunun karşılığında "bir puan verilmesi (k8)", "performansa dayalı hakem kurulu üyeliği verilmesi (k13)", "hakemlerin uzmanlık alanlarına göre seçilmesi (k12k16)" şeklindedir. Ayrıca "hakemlerin inceleme için bir eğitim almasının gerekli olduğu (k6)" konusuna da değinilmiştir.

Editörler ile ilgili öneriler, çeşitlilik arz eden bir görünüme sahiptir. Bir katılımcı (k1), radikal bir öneriyle, sürecin iyileşebilmesi için "editörlerin tamamının emekliye ayrılması" gerektiğini vurgulamaktadır. Dahası, bu katılımcı "hakem belirleme işleminin editörce değil, bir sistem aracılığıyla otomatik olarak yapılmasını" önermektedir. Başka bir katılımcının (k14) önerisi ise buna benzemektedir: "yazar ve hakemlerin arada editör olmadan iletişime geçmesi gerekmektedir". "Makalelerin sayfa sayısının azaltılması gerektiği (k8)" önerisi de dergi editörlüğü kapsamında değerlendirilebilir.

Son olarak hakemlik sürecinin daha hızlı ilerleyebilmesi adına yazar ve hakemlerin de sorumlulukları bulunduğu vurgulanmaktadır. Bu kapsamda bir katılımcı (k2), "yazar, sanki kendisi hakemlik yapacakmış gibi özenerek yazmalı, hakem de sanki kendi makalesini inceliyormuş gibi incelemeli" şeklinde bir öneri sunmaktadır.

\section{SONUÇ VE DEĞERLENDİRME}

Yüzyıllardır uygulanan hakemlik süreci, bilginin doğruluğu, gelişimi, yayılımı ve belki de en önemlisi objektifliğinin sağlanabilmesi açısından önemli bir misyon yüklenmiştir. Çeşitli araştırmalarda, özellikle tek/çift-körleme hakemlik süreçlerine karşı farklı bilim dallarından akademisyenlerin olumlu bir bakış açısına sahip oldukları tespit edilse de özellikle bu iki sistem son dönemlerde bazı açılardan eleştirilere konu olmaktadır. Bu çalışma, turizm akademisyenlerinin ÇK'nın kalite artışına ne derece olanak tanıdığını ve sürecin avantaj/dezavantajları hakkındaki düşüncelerini tespit etmek ve sistemin iyileştirilmesi bakımından varsa önerileri almak amacındadır.

Çalışmanın sonuçlarına göre turizm akademisyenlerinin büyük oranda ÇK'dan memnun oldukları söylenebilmektedir. Aynı zamanda turizm akademisyenleri ÇK'nın kalite artışı sağladığını da düşünmektedir. ÇK'nın en önemli iki avantajı objektiflik ve kalite güvencesi sağlaması olarak görülürken; zaman ve hakemlerin özensiz incelemeleri dezavantajlar noktasında öne çıkmaktadır. Sonuçlar bu haliyle pazarlama ve hemşirelik gibi alanlardaki akademisyenlerin görüşleri ile paralellik arz etmektedir. Bu bakımdan, tek/çift-körleme hakemlik süreçlerine alternatif olarak geliştirilmeye çalışılan açık ya da yayım sonrası hakemlik süreçlerinin gerekliliği konusu tartışmalı hale gelmektedir. Çünkü akademisyenler mevcut hakemlik sistemlerden zaten memnundurlar. Bu çabaların yerine ÇK ile ilgili gündeme gelen bazı eksikliklerin giderilmeye çalışılması, akademisyenlerin ÇK'ya karşı duydukları memnuniyeti daha da artırabilir.

Turizm akademisyenleri, ÇK'nın eksikliklerinin giderilebilmesi ve eleştirilerin ortadan kalkabilmesi için en önemli sorumlulukların hakemlere ve editörlere düştügü görüşündedir. Esasında hakemlerle ilgili yapılan öneriler, dergi sahiplerinin veya editörlüklerinin yardımıyla yapılabilecek hususlar olarak da görülebilir. Örneğin, hakemlere ödeme yapılması veya bunların eğitim almalarının sağlanması bu kapsamda değerlendirilebilir. Editörlerle ilgili önerilenler ise 
sistemsel bazı değişikliklerin yapılması ile uygulamaya geçebilecek cinstendir. Örneğin, hakem belirleme işleminin editörlerce değil, bir sistem aracılığıyla yapılması ancak bu konuda ayrı bir altyapının kurulması ile hayata geçirilebilecektir.

Unutulmamalıdır ki hakemlik süreci, insanın yer aldığı bir süreç olduğundan hatalara her zaman açiktır. Fakat bu süreçte kalitenin daha da artırılabilmesi için doğruluk, güvenirlik, tarafsızlık ve nesnellik ilkeleri olabildiğince sağlanmalıdır. Buna dayanarak süreç, başta yazar, editör, hakem olmak üzere kapsamına giren herkesi görev bilinci ve bilimsel etik açısından sorumlu kılmaktadır. Bu şartlar sağlanmadığı takdirde, hangi sistem/uygulama getirilirse getirilsin doğru, güvenilir ve tarafsız bilgininin yayılması zorlaşabilecektir.

Bu araştırmada bazı sınırlılıklar bulunmaktadır. İlk olarak evrenin küçük ölçekli bir yapıya sahip olması en büyük sınırlılık olarak ifade edilmelidir. Bu nedenle, turizm fakültelerinde görev alan ve hakemlik yapmış diğer akademisyenlerin de evrene dahil edilerek daha kapsamlı araştırmaların yürütülmesi, bu araştırmada ortaya çıkan fikirlerin çeşitlenebilmesi ve genel görüş olarak dile getirilebilmesi açısından önem taşımaktadır. Ayrıca sonraki araştırmalarda, hakemlerin demografik özellikleri ile görüşleri arasındaki olası ilişki, Türkiye ve yurtdışındaki hakemlerin görüşlerinin karşılaştırılması gibi konular potansiyel araştırma sahaları olarak görülebilir.

\section{KAYNAKÇA}

Altunışık, R., Coşkun, R., Bayraktaroğlu, S. ve Yıldırım, E. (2010). Sosyal Bilimlerde Araştırma Yöntemleri: SPSS Uygulamalı. (6. Baskı). Sakarya: Sakarya Yayıncılık.

Aydın, R. ve Yüksel, A. (2013). Bilimsel Dergilerde Değerlendirme: Hakemler Neden Görev Alır? Tralleis Elektronik Dergisi, 1(1): 1-10.

Baggs, J., Broome, M., Dougherty, M., Freda, M. and Kearney, M. (2008). Blinding in Peer Review: The Preferences of Reviewers for Nursing Journals. Journal of Advanced Nursing, 64(2): 131-138.

Bailey, C., Hair, J., Hermason, D. and Crittenden, V. (2012). Marketing Academics' Perceptions of the Peer Review Process, Marketing Education Review, 22(3): 263-278.

Bailey, C., Hermason, D. and Tompkins, J. (2008a). The Peer Review Process in Finance Journals. Journal of Financial Education, 34: 1-27.

Bailey, C., Hermason, D. and Lowers, T. (2008b). An Examination of the Peer Review Process in Accounting Journals. Journal of Accounting Education, 26: 55-72.

Baldwin, M. (2018). Scientific Autonomy, Public Accountability, and the Rise of "Peer Review" in the Cold War United States. Isis, 109(3): 538-558.

Bornmann, L. and Daniel, H. (2010). The Manuscript Reviewing Process: Empirical Research on Review Requests, Review Sequences, and Decision Rules in Peer Review. Library \& Information Science Research, 32: 5-12.

Bravo, G., Grimado, F., Inesta, E., Mehmani, B. and Squazzoni, F. (2019). The Effect of Publishing Peer Review Reports on Referee Behavior in Five Scholarly Journals. Nature Communications, 10(322): 1-8.

Correia, A. and Kozak, M. (2017). The Review Process in Tourism Academia: An Elaboration of Reviewers' Extrinsic and Intrinsic Motivations. Journal of Hospitality and Tourism Management, 32: $1-11$. 
Dilek-Kayaoğlu, H. ve Gülle, T. (2015). Türkiye'de Toplumsal Bilimler ve İnsan Bilimleri Dergilerinde Hakemlik Süreci: Yazar, Hakem ve Editör Bakış Açılarından Bir İnceleme. Türk Kütüphaneciliği, 29(3): 391-432.

Erdoğan, İ. (2001). Sosyal Bilimlerde Pozitivist-Ampirik Akademik Araştırmaların Tasarım ve Yöntem Sorunları. Anatolia: Turizm Araştırmaları Dergisi, 12(1): 119-134.

Glonti, K. and Hren, D. (2018). Editors' Perspectives on the Peer-Review Process in Biomedical Journals: Protocol for a Qualitative Study. BMJ Open, 8: 1-7.

Greaves, S., Scott, J., Clarke, M., Miller, L., Hannay, T., Thomas, A. and Campbell, P. (2006). Nature's Trial of Open Peer Review. Nature Online Peer Review Debate. https://www.nature.com/nature/peerreview/debate/nature05535.html [Erişim Tarihi: 19.06.2019].

Göktaş, Y., Küçük, S., Aydemir, M., Telli, E., Arpacık, Ö., Yıldırım, G. ve Reisoğlu, İ. (2012). Türkiye'de Eğitim Teknolojileri Araştırmalarındaki Eğilimler: 2000-2009 Dönemi Makalelerinin İçerik Analizi. Kuram ve Uygulamada Eğitim Bilimleri, 12(1): 177-199.

Hall, C. M. and Valentin, A. (2005). Content Analysis. (Editör) Ritchie, B.W., Burns, P. ve Palmer, C.: Tourism Research Methods: Integrating Theory with Practice içinde (ss. 191-209) UK: Cabi Publishing.

Hames, I. (2007). Peer Review and Manuscript Management in Scientific Journals. USA: Blackwell Publishing.

Hill, J. (2016). How to Review a Manuscript, Journal of Electrocardiology, 49: 109 - 111.

Koop, T. and Pöschl, U. (2006). An Open, Two-Stage Peer-Review Journal. Nature Online Peer Review Debate. https://www.nature.com/nature/peerreview/debate/nature04988.html, [Erişim Tarihi: 19.06.2019].

Kronick, D. (1990). Peer Review in 18th-Century Scientific Journalism. JAMA, 263(10): 1321-1322.

Leung, D., Law, R., Kucukusta, D. and Guillet, B. D. (2014). How to Review Journal Manuscripts: A Lesson Learnt from the World's Excellent Reviewers. Tourism Management Perspectives, 10: 4656.

Önder, İ. (2006). Hakem ve Jüri Sistemlerinde Aleniyet. Sosyal Bilimlerde Süreli Yayıncılık I. Ulusal Kurultay Bildirileri, 2-3 Kasım 2006, Ankara, ss: 49-52.

Sanchez, I., Makkonen, T. and Williams, A. (2019). Peer Review Assessment of Originality in Tourism Journals: Critical Perspective of Key Gatekeepeers. Annals of Tourism Research, 77: 1-11.

Seaton, A. V. (1996). Blowing the Whistle on Tourism Referees. Tourism Management, 17(6): 397399.

Shani, A. (2018). Reviewing Articles for Tourism and Hospitality Journals: An Altruistic Academic Tradition or a Service to be paid for? Int. J. Tourism Policy, 8(1): 73-82.

Snell, L. and Spencer, J. (2005). Reviewers' Perceptions of the Peer Review Process for a Medical Education Journal. Medical Education, 39: 90-97.

Şahin, A. E. (2006). Eğitim ile İlgili Süreli Dergilerde Hakemlik ve Sorunları: Eğitim Araştırmaları Dergisi Örneği. Sosyal Bilimlerde Süreli Yayıncllık I. Ulusal Kurultay Bildirileri, 2-3 Kasım 2006, Ankara. ss.63-66. 
Tan, M. (2018). Peer Review - Past, Present and Future, (Editör) Markovac, J., Kleinman, M. ve Englesbe, M.: Medical and Scientific Publishing Author, Editor, and Reviewer Perspectives içinde (ss.5568) USA: Academic Press.

Ware, M. (2008). Peer Review: Benefits, Perceptions and Alternatives. England: Publishing Research Consortium.

Ware, M. (2011). Peer Review: Recent Experience and Future Directions. New Review of Information Networking, 16(1): 23-53.

Ware, M. (2013). Peer Review: An Introduction and Guide. England: Publishing Research Consortium.

Ware, M. and Mabe, M. (2015). The STM Report: An Overview of Scientific and Scholarly Journal Publishing. The Netherlands: International Association of Scientific, Technical and Medical Publishers.

Winck, J. C., Fonseca, J., Azevedeo, L. and Wedzicha, J. (2011). To publish or perish: How to review a manuscript. Rev Port Pneumol, 17(2): 96-103.

Yuksel, A. (2003). Writing publishable papers. Tourism Management, 24: 437-446.

Yüksel, A. (2002). Turizm Alanındaki Dergilerde Akademik İçerikli Makale Değerlendirmede Hakemlerce Gözetilen Ölçütler. Anatolia: Turizm Araştırmaları Dergisi, 13(2): 139-147. 